\title{
Impact of Typical Faults Occurring in Demand-controlled Ventilation on Energy and Indoor Environment in a Nordic Climate
}

\author{
Kamilla Heimar Andersen ${ }^{1,2, *}$, Sverre B. Holøs ${ }^{1}$, Aileen Yang ${ }^{3}$, Kari Thunshelle ${ }^{1}$, Øystein Fjellheim ${ }^{1}$, and Rasmus Lund \\ Jensen $^{2}$
}

${ }^{1}$ SINTEF Community, Architectural Engineering, 0373 Oslo, Norway

${ }^{2}$ Aalborg University, Civil Engineering Department, 9220 Aalborg East, Denmark

${ }^{3}$ OsloMet - Oslo Metropolitan University, 0130 Oslo, Norway

\begin{abstract}
This study evaluates typical faults occurring in demand-controlled ventilation (DCV) system and the impact on three output results: energy use, thermal comfort, and indoor air quality. The methodologies used in this study were qualitative interviews of selected Norwegian Heating Ventilation Air Condition (HVAC) system experts and numerical modeling using the building performance simulation tool IDA ICE. The faults deduced from the qualitative interviews were modeled as the fault's different consequences to account for a large variety of faults. With a Norwegian school classroom as a case study, a local approach applying a one-at-atime (OAT) simulation was used to perform an analysis of the extreme fault conditions that can occur. The results from the fault modeling demonstrated that greater attention is needed to avoid faults in the HVAC systems due to its impact on the indoor environment quality and energy efficiency of buildings.
\end{abstract}

\section{Introduction}

In order to tackle the urgent environmental issues of our modern society and improve the overall life quality of the population, the building sector appears as a clear key target [1]. Indeed, the building sectors account for more than $40 \%$ of the total energy needs and a third of the $\mathrm{CO}_{2}$ emissions [2]. In addition, modern humans spend 80-90 $\%$ of their time inside an enclosed space [3]. The quality of their indoor environment has thus a major impact on their well-being, health, and productivity [4].

Heating Ventilation and Air Conditioning (HVAC) systems provide occupants with a comfortable indoor environment, which includes, among others, fresh air. The latter is a key parameter for a healthy indoor space. In addition, a traditional HVAC system normally consumes up to $30 \%$ of the total energy use in a building [5].

In recent years, detecting and preventing faults from occurring in HVAC systems is raising more and more attention [6-8] as they have been found to have a preponderant impact on the building energy needs and the indoor environment quality [9-11]. However, further efforts are needed to develop and implement efficient strategies for the design, commissioning, maintenance, and repair of HVAC systems, and especially ventilation systems.

The popularity of DCV has strongly increased due to system flexibility and its potential for energy savings [1215]. Nonetheless, there is a lack of studies concerning the typical faults, errors, or malfunctions occurring in such systems in Nordic countries.

The aim of this study is to evaluate the energy use, thermal comfort, and indoor air quality of a Norwegian school equipped with demand-controlled ventilation (DCV) when typical faults occur.

The initial phase of the current investigation consists of interviewing different professionals in the field of HVAC systems in order to identify typical faults. Based on the analysis of those qualitative interviews, several typical faults are identified. The impact of the identified faults on the energy use and indoor environment is examined by performing a sensitivity analysis using the building simulation tool IDA ICE.

\section{Study case}

The study case is the Fernanda Nissen (FN) elementary school located in the center of Oslo, Norway. The school was completed in 2016, and fully operational in 2017. It was built in accordance with the Norwegian passive house standard NS 3701:2012. One can see in Figure 1 an illustration of the Fernanda Nissen elementary school in south-east orientation.

The school has balanced mechanical ventilation. The ventilation is demand-controlled by DCV-dampers, where the airflow rate is modulated between a minimum $\left(\mathrm{V}_{\min }\right)$ and maximum $\left(\mathrm{V}_{\max }\right)$ value. The $\mathrm{DCV}$-damper control is performed by adjusting the position of the damper according to a demand airflow rate that is calculated based on the indoor environmental quality in each room (indoor temperature and $\mathrm{CO}_{2}$ concentration measurement). A general description of a DCV-damper can be seen in Figure 2. The measuring cross and the manometer measure the actual airflow rate in the duct and

\footnotetext{
* Corresponding author: kamilla.andersen@sintef.no
} 
send this feedback information to the airflow controller. The airflow controller then sends a control signal (0-10 V) to the actuator which adjusts the position of the damper, and thus the airflow supplied to the classroom to match the setpoint (demand airflow rate) [16].

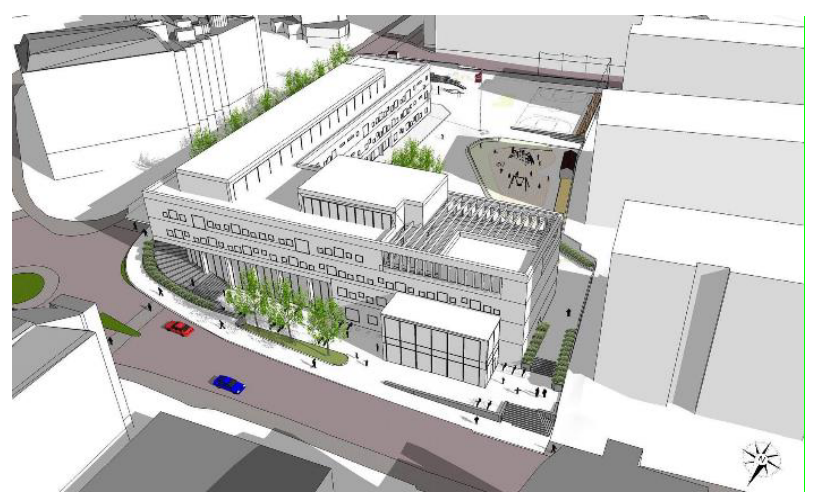

Fig. 1. Fernanda Nissen elementary school. Image sources: http://larklandskap.no/ and https://www.planforum.no/.

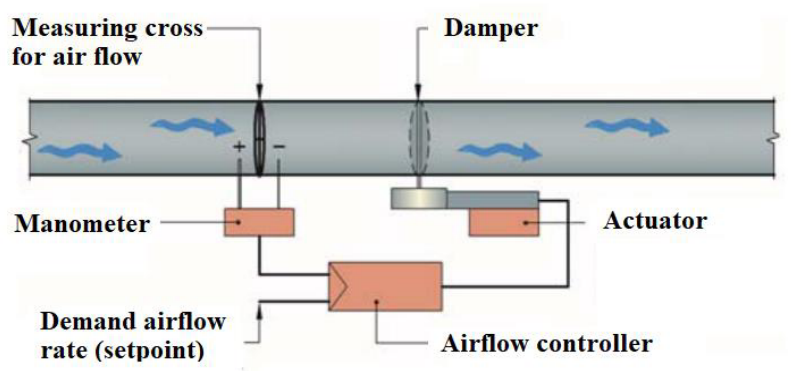

Fig. 2. A general schematic illustration of a DCV-damper [15].

Other ways of controlling DVC-dampers are further described here [15].

\section{Methodologies}

\subsection{Qualitative interviews}

To investigate which typical faults can occur in DCVsystems in schools, offices, and other types of large buildings, qualitative interviews were the starting point in this study. In total, 11 different HVAC system professionals were interviewed; six representatives from consulting, two working as central facility managers, and three contractors. The interview objects criteria were the following: Minimum ten years of work experience within the building sector or ventilation industry in Norway as either a researcher, civil engineer, consultant, contractor, as an operation facility manager, or as an electrical engineer.

\subsection{Fault modeling}

After the analysis of the qualitative interviews, four faults were chosen to fault-model based on faults and symptoms of possible consequences provided from the interview objects shown in Table 3.

Our fault modeling is based on the many suitable methodologies suggested by Li et al. [17]. In short, this fault modeling consists of changing the input building parameters of the HVAC system to represent faults suggested as one of the methods by Haves [18].

\subsubsection{Numerical simulations in IDA ICE}

The numerical model made in IDA ICE was based on a single classroom from the school. Five surfaces were treated as internal rooms. One wall was facing outdoors in north-east orientation. One year was simulated (365 days) with the weather file: Oslo, Fornebu 014880 (IWEC) from EnergyPlus. The geometrical model from IDA ICE can be seen in Figure 3.

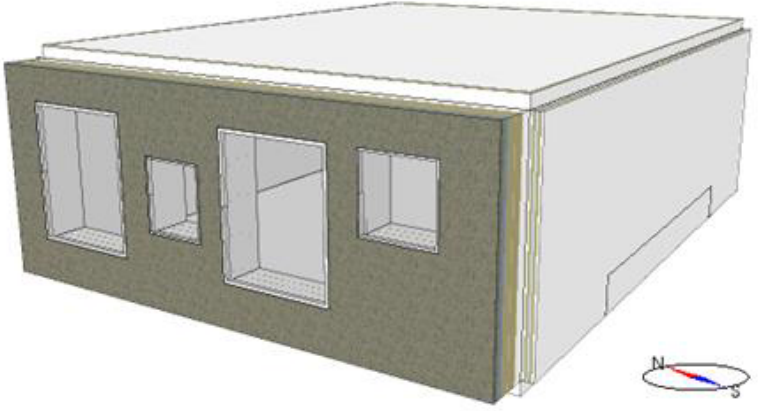

Fig. 3. Geometrical model in IDA ICE.

The DCV implemented in the IDA ICE model uses temperature and $\mathrm{CO}_{2}$ concentration sensors with a linear control between $\mathrm{V}_{\min }$ and $\mathrm{V}_{\max }$ (PID-controller). The Air Handling Unit (AHU) is simulated with a constant pressure difference in both the supply and exhaust ducts.

General inputs in the numerical simulations in IDA ICE are described in Table 2.

Table 1. General inputs in IDA ICE simulations which are representative for all IDA ICE models.

\begin{tabular}{|c|c|}
\hline Parameter & Value \\
\hline Classroom area & $60 \mathrm{~m}^{2}(6 \times 10 \mathrm{~m})$ \\
\hline Ceiling height & $2.8 \mathrm{~m}$ \\
\hline Occupants & $\begin{array}{c}31 \text { occupants, } 1 \text { met } \\
\text { (From the school design) }\end{array}$ \\
\hline $\mathrm{CO}_{2}$ emission per person & IDA ICE default equation \\
\hline Lights & 360 W (NS 3031:2014) \\
\hline Equipment & $600 \mathrm{~W}$ (NS 3031:2014) \\
\hline $\begin{array}{c}\text { Electric radiator } \\
\text { (Typical heating system } \\
\text { in Norway) }\end{array}$ & $\begin{array}{c}\text { Yes, } 2 \mathrm{~kW} \\
\left(\text { Thermostat setpoint } 19^{\circ} \mathrm{C}\right)\end{array}$ \\
\hline Solar shading & $\begin{array}{c}\text { External blinds } \\
\text { (Activated at } 75 \mathrm{~W} / \mathrm{m}^{2} \text { ) }\end{array}$ \\
\hline $\begin{array}{l}\text { Occupancy schedule } \\
\text { Monday - Friday }\end{array}$ & $\begin{array}{l}08: 30-11: 00 \\
12: 00-15: 00\end{array}$ \\
\hline
\end{tabular}




\begin{tabular}{|c|c|}
\hline $\begin{array}{c}\text { Ventilation operation time } \\
\text { (No weekends, national } \\
\text { holidays or vacation } \\
\text { operation) }\end{array}$ & 07:30-16:00 \\
\hline Ventilation airflow rate & $\begin{array}{c}\mathrm{V}_{\min } 150 \mathrm{~m}^{3} / \mathrm{h} \\
\mathrm{V}_{\max } 1060 \mathrm{~m}^{3} / \mathrm{h} \\
\text { (Norwegian building } \\
\text { regulations) }\end{array}$ \\
\hline SFP factor & $\begin{array}{c}1,5 \mathrm{~kW} /\left(\mathrm{m}^{3} / \mathrm{s}\right) \\
\text { (Treated as constant, BPS } \\
\text { limitations) }\end{array}$ \\
\hline Heat exchanger efficiency & $80 \%$ \\
\hline Total window area & $\begin{array}{c}7 \mathrm{~m}^{2} \\
(\text { WWR } 42 \%)\end{array}$ \\
\hline U-value external wall & $\begin{array}{c}0.11 \mathrm{~W} / \mathrm{m}^{2} \mathrm{~K} \\
(\mathrm{NS} 3701: 2012)\end{array}$ \\
\hline U-value window & $\begin{array}{c}0.8 \mathrm{~W} / \mathrm{m}^{2} \mathrm{~K} \\
(\mathrm{NS} 3701: 2012)\end{array}$ \\
\hline g-value window (SHGC) & 0.30 \\
\hline Airtightness at $50 \mathrm{~Pa}$ & $0.6 \mathrm{~h}^{-1}$ \\
\hline Leak area & $\begin{array}{c}\text { External wall: } 0.00606 \mathrm{~m}^{2} \\
\text { Door: } 0.02 \mathrm{~m}^{2}\end{array}$ \\
\hline $\begin{array}{c}\text { Timestep } \\
\text { (convergence achieved) }\end{array}$ & $\begin{array}{c}0.0833 \mathrm{~h} \\
5 \text { minutes interval }\end{array}$ \\
\hline $\begin{array}{c}\text { Outdoor } \mathrm{CO}_{2} \\
\text { concentration } \\
\text { (Oslo based number) }\end{array}$ & $450 \mathrm{ppm}$ \\
\hline
\end{tabular}

\subsubsection{Local approach}

Table 1 shows the chosen parameters to fault-model: (1) maximum supply airflow, (2) maximum exhaust airflow, (3) supply air temperature, and (4) $\mathrm{CO}_{2}$ concentration setpoint. These parameters are based on the consequences shown in Table 3 . The offset values were selected based on the interviews. A local approach, one-at-a-time (OAT) simulation was performed to investigate the consequences of the offset values.

Firstly, the fault-free (reference) model was created and simulated. Secondly, eight models were changed OAT based on their offset value. To make this process efficient and automatic, internal programming (macro) in IDA ICE was used for the simulation process. The macro consisted of a setup of sequential pre-defined parametric changes in each of the eight faulty models (described in Table 1) in IDA ICE. Lastly, the results consisted of calculating the differences between the reference model and the faulty models of the output results: energy use, thermal comfort, and indoor air quality. All faults were simulated a whole year (365 days) with a representative weather file.

Table 2. Local approach varying OAT faults with offset values deduced from the interview objects and based on Norwegian Standards and guidelines.

\begin{tabular}{|c|c|c|c|}
\hline Fault number & Reference & $\begin{array}{c}\text { Offset } \\
\text { low }\end{array}$ & $\begin{array}{c}\text { Offset } \\
\text { high }\end{array}$ \\
\hline $\begin{array}{c}\text { Maximum supply } \\
\text { airflow }\left(1 / \mathrm{s} \mathrm{m}^{2}\right)\end{array}$ & 4.9 & 3.4 & 6.3 \\
\hline
\end{tabular}

\begin{tabular}{|c|c|c|c|}
\hline $\begin{array}{c}\text { 2: } \\
\text { Maximum exhaust } \\
\text { airflow }\left(1 / \mathrm{s} \mathrm{m}^{2}\right)\end{array}$ & 4.9 & 3.4 & 6.3 \\
\hline $\begin{array}{c}3: \\
\begin{array}{c}\text { Supply air } \\
\text { temperature }\left({ }^{\circ} \mathrm{C}\right)\end{array}\end{array}$ & Temp. curve & 17 & 25 \\
\hline $\begin{array}{c}4: \\
\mathrm{CO}_{2} \text { concentration } \\
\text { setpoint }(\mathrm{ppm})\end{array}$ & 800 & 500 & 1200 \\
\hline
\end{tabular}

Reference: A well operating and functioning HVAC system is simulated with the reference values shown in Table 1. The supply air temperature is controlled with an outdoor temperature compensation curve. The HVAC system is designed to supply fresh air at $17{ }^{\circ} \mathrm{C}$ when the outdoor temperature is $20^{\circ} \mathrm{C}$ and above, and supply with $21{ }^{\circ} \mathrm{C}$ with outdoor temperatures lower than $10^{\circ} \mathrm{C}$. The $\mathrm{CO}_{2}$ concentration setpoint was set to $800 \mathrm{ppm}$, and the airflow rate is balanced with $4.91 / \mathrm{s} \mathrm{m}^{2}$.

Fault 1 \& 2 Maximum supply- and exhaust airflow rate: The maximum supply- and exhaust airflow $\left(\mathrm{V}_{\max }\right)$ was varied $30 \%$ positive and negative of the reference value. This to simulate situations with over- and under pressure, in addition to less or more air supplied to the classroom. As shown in Table 2, the minimum supplyand exhaust airflow rate $\left(\mathrm{V}_{\min }\right)$ was kept constant at the designed value. When unbalance is simulated, IDA ICE will compensate by either increase the infiltration or exfiltration in the classroom. Therefore, leak areas have been defined in the model.

Fault 3 Supply air temperature: The supply air temperature is normally controlled by a compensated outdoor curve during the cooling season if cooling is installed. During the heating season, a constant supply air temperature of $21^{\circ} \mathrm{C}$ is often implemented since cooling is rarely needed during the heating season in Nordic countries. However, for this fault, constant ventilation cooling or heating was implemented at either $17^{\circ} \mathrm{C}$ or 25 ${ }^{\circ} \mathrm{C}$ (low and high fault).

Fault $4 \mathrm{CO}_{2}$ concentration setpoint: The $\mathrm{CO}_{2}$ concentration setpoint is normally set to $800 \mathrm{ppm}$ in classrooms in Norway (can differ, usually depends on the municipality). However, varying this setpoint, the $\mathrm{CO}_{2}$ concentration can exceed the chosen setpoint, supplying lower- or higher airflow.

\section{Results and discussion}

\subsection{Qualitative interview results}

Often, symptoms and faults are coinciding, as one symptom may be associated with a handful of faults, or one fault may have many different symptoms. In our study, we do not distinguish between faults and symptoms as both causes and consequences are analyzed. The top 10 faults from the qualitative interviews are described in Table 3, ranked based on their occurrence mentioned by the interview objects. The causes and the consequences of these faults are also shown in Table 3. The top five faults from the qualitative interviews were (1) Ventilation unbalance, (2) Incorrect or unsuitable placement of $\mathrm{CO}_{2}$ concentration and/or temperature sensor, (3) Noticeable 
noise, (4) No access to DCV-damper and (5) Lower or higher airflow than designed supplied to a room.

Adopting the fault definitions from Annex 25 [5], installation faults can be defined as, for example ventilation installation with wrong control logic or incorrect implementation. Generally, the majority of the faults found in this study are due to improper installation based on their possible causes. Installation faults can lead to both gradual or sudden faults, where the HVAC system would, in the worst-case scenario, require downtime to fix components or parts of the HVAC system. However, many installation faults may be prevented if protocols, commissioning, or load-tests were performed correctly.

Using qualitative interviews to investigate what typical faults can occur in the HVAC system has shown to be a reliable methodology and has also been used in other similar studies on fault modeling [19]. For example, Qin et al. [10] asked ten professionals to assess the top 10 faults occurring in mechanical ventilation systems, of which poor IAQ, deviation in room temperature, and the difference in actual air volume flow were some of the faults mentioned. Literature reviews are also a way to discover typical faults and have been applied to several studies [9] [20-22]. However, as there are many different possibilities to control the DCV-dampers, it was exigent to figure out what type of damper control (CO2 concentration, temperature, or combined) and ventilation control-principle the ventilation system utilized in the evaluated studies. Nevertheless, both methodologies seem to agree with our study, despite geographical differences

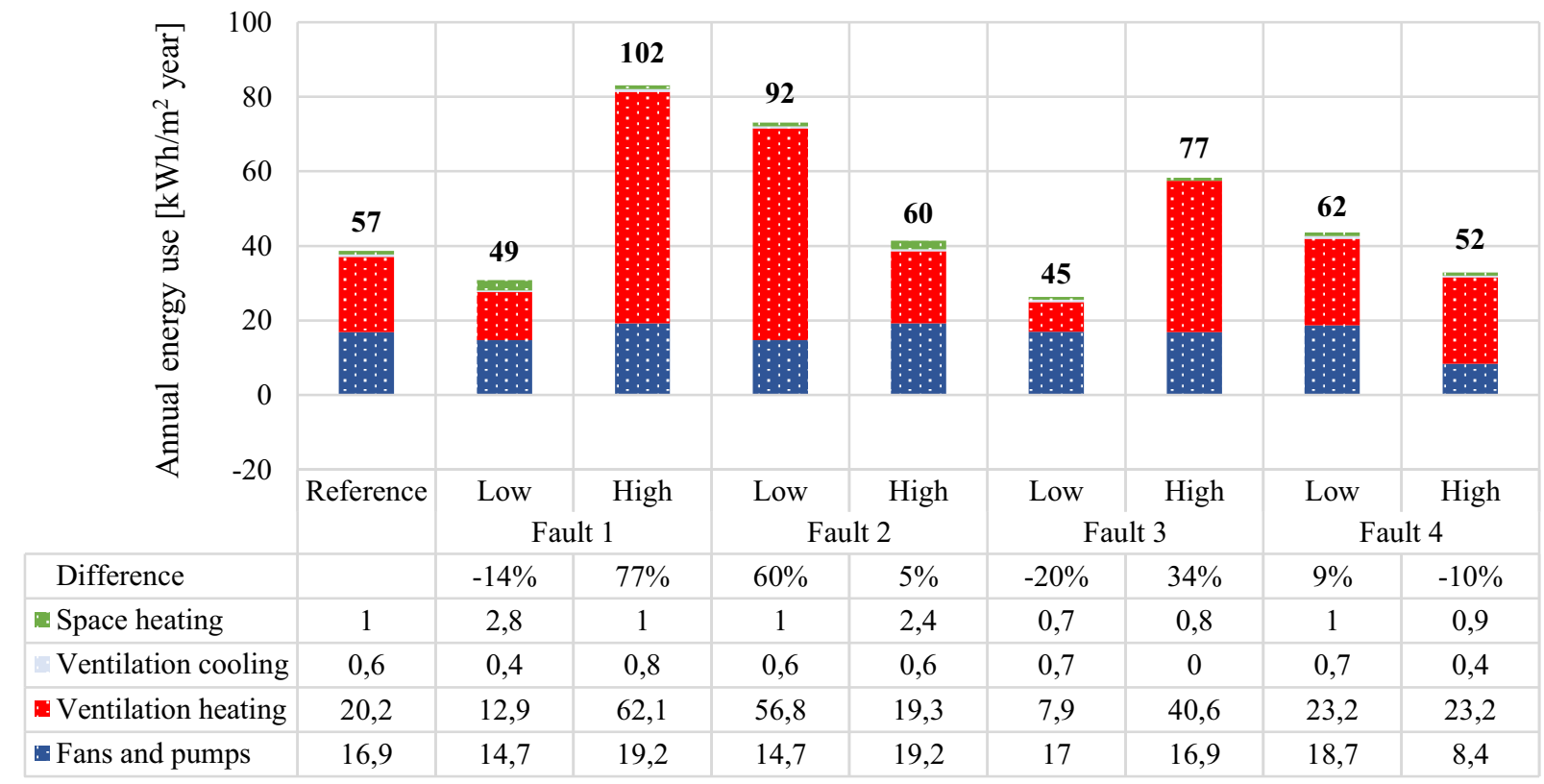

Fig. 4. Reference and eight faulty models presented with the annual energy use. Lights and equipment are not shown in the figure. The annual energy use (including lights and equipment) is presented above each histogram. Fault 1: Maximum supply airflow, Fault 2: Maximum exhaust airflow, Fault 3: Supply air temperature, Fault 4: $\mathrm{CO}_{2}$ concentration. Electricity is not included in the graph as they are constant values.

\subsection{Energy use}

The energy use $\left(\mathrm{kWh} / \mathrm{m}^{2}\right.$ year) investigated in this study consists of fans and pumps, ventilation heating and cooling, and space heating (electric radiator).

Annual energy use for lights and equipment was estimated to 7 and $11.6 \mathrm{kWh} / \mathrm{m}^{2}$ year, respectively. These parameters are kept constant and not further investigated in this study. However, they are included in Figure 4. Figure 4 illustrates the annual energy use divided into the mentioned categories above, each histogram describes the representative fault, and the annual energy use for each category is presented above the histograms. The faults providing the highest energy use are the following: (1) Fault 1 high supply airflow, (2) Fault 2 low exhaust airflow, and (3) Fault 3 high supply air temperature.

Fault 1 high (supply airflow) and Fault 2 low (exhaust airflow) are in general simulated with overpressure, either by supply- or exhaust airflow. These two faults increased the energy use by 45 and $35 \mathrm{kWh} / \mathrm{m}^{2}$ year, $(77 \%$ and 60 $\%)$ respectively. This is because of the need for higher ventilation heating due to increased exfiltration when underpressure (Fault 1 low). Exfiltration leads to increased heating or cooling demand, as a smaller proportion of the airflow passes the heat recovery unit. Also, during cold outdoor conditions, exfiltration increases interstitial condensation risk. Thus, infiltration is considered less problematic than exfiltration in cold or cool climates. 
Table 3. Results from the qualitative interviews. Faults and symptoms, causes and consequences presented in each row.

\begin{tabular}{|c|c|c|c|}
\hline $\begin{array}{l}\text { Fault } \\
\text { no. }\end{array}$ & Faults and symptoms & Causes of faults and symptoms & Consequences \\
\hline 1 & $\begin{array}{l}\text { Ventilation unbalance } \\
\text { (doors are hard to open } \\
\text { or close) }\end{array}$ & $\begin{array}{l}\text { - DCV-damper (either supply or exhaust) are mounted after } \\
\text { rehabilitation, no balanced ventilation or commissioning is } \\
\text { provided } \\
\text { - Rooms with large deviations increased the pressure } \\
\text { - Wear and tear of the system } \\
\text { - Not sufficient or satisfactory commissioning (commissioned } \\
\text { with noticeable over- or under pressure) } \\
\text { - Load testing of the ventilation system improper or neglected } \\
\text { - Complex ventilation system } \\
\text { - Cracks or punctures in duct system (airtightness test not } \\
\text { performed) }\end{array}$ & $\begin{array}{l}\text { Overpressure or under pressure have } \\
\text { occurred, ventilation airflows not } \\
\text { balanced), fan needs to work at a higher } \\
\text { level - increasing the energy } \\
\text { consumption, lower or higher supply of } \\
\text { air which can make the occupants feel } \\
\text { draft, too warm and will decrease } \\
\text { performance }\end{array}$ \\
\hline 2 & $\begin{array}{l}\text { Incorrect, unsuitable } \\
\text { placement or non- } \\
\text { working } \mathrm{CO}_{2} \text {, pressure } \\
\text { and/or temperature } \\
\text { sensor }\end{array}$ & $\begin{array}{l}\text { - No calibration of the sensors in DCV-damper and the room } \\
\text { - Defective component or controller failure } \\
\text { - Improper installation } \\
\text { - Room structure not optimal for sensor placement } \\
\text { - Wrong component connection (no insulation/airtightness in } \\
\text { the cables so } \mathrm{CO}_{2} \text { concentration sensor measures outdoor } \\
\text { concentration) }\end{array}$ & $\begin{array}{l}\text { Deviating supply air temperature and } \\
\text { supply airflow, higher } \mathrm{CO}_{2} \\
\text { concentration, unsatisfied occupants, } \\
\text { draft may also occur if the combined } \\
\text { sensor shows higher temperature and } \\
\mathrm{CO}_{2} \text { concentration than actual room } \\
\text { temperature }\end{array}$ \\
\hline 3 & $\begin{array}{l}\text { Noticeable noise from } \\
\text { the ventilation system }\end{array}$ & $\begin{array}{l}\text { - Sound silencer/insulation not mounted with DCV-damper } \\
\text { (forgotten or neglected) } \\
\text { - Wear and tear of fan bearings } \\
\text { - Wrong placement of DCV-damper which provides incorrect } \\
\text { actuator point }\end{array}$ & $\begin{array}{l}\text { Noise will be noticeable and } \\
\text { bothersome, unsatisfied occupants }\end{array}$ \\
\hline 4 & $\begin{array}{l}\text { No access to DCV- } \\
\text { damper }\end{array}$ & $\begin{array}{l}\text { - Low ceiling, DCV-damper does not fit properly } \\
\text { - Design of DCV-damper } \\
\text { - No cleaning hatch for removing dust and dirt from the } \\
\text { measuring cross. } \\
\text { - The ceiling is hard to remove/require demolition }\end{array}$ & $\begin{array}{l}\text { Deviating supply- and exhaust airflow if } \\
\text { measuring cross is dusted, higher } \mathrm{CO}_{2} \\
\text { concentration due to dust and dirt on } \\
\text { measuring cross, unsatisfied occupants } \\
\text { due to the aforementioned reasons }\end{array}$ \\
\hline 5 & $\begin{array}{l}\text { Lower or higher airflow } \\
\text { than designed supplied } \\
\text { to a room }\end{array}$ & $\begin{array}{l}\text { - Electrical error or component error which makes the fire } \\
\text { valve close } \\
\text { - Frozen DCV-damper sensor } \\
\text { - Low fan speed } \\
\text { - Clogged, damaged or dirty coils } \\
\text { - Wrong choice of duct dimensions }\end{array}$ & $\begin{array}{l}\text { Deviating supply- and exhaust airflow } \\
\text { from designed value, higher } \mathrm{CO}_{2} \\
\text { concentration, unsatisfied occupants }\end{array}$ \\
\hline 6 & $\begin{array}{l}\text { Users complain about a } \\
\text { too cold or too warm } \\
\text { environment }\end{array}$ & $\begin{array}{l}\text { - Wrongly designed airflow rate } \\
\text { - Non-strategically placement of room sensors contributing to } \\
\text { the wrong reading to damper or not connected to BMS at all } \\
\text { - Sensors have not been calibrated providing the wrong } \\
\text { temperatures } \\
\text { - DCV-dampers is placed to close after bend which provides a } \\
\text { wrongly measured airflow rate } \\
\text { - Not optimal design of air intake (placed in the sun or } \\
\text { exposed to wind) } \\
\text { - No ventilation cooling is installed } \\
\text { - Broken heating- or cooling coil } \\
\text { - Components wrongly connected during commissioning or } \\
\text { inspection } \\
\text { - Higher occupancy load than designed } \\
\text { - Malfunction/fouling in the control valve of the heating and } \\
\text { cooling coil } \\
\text { - Wrong duct size which provides low-pressure differences }\end{array}$ & $\begin{array}{l}\text { Deviating supply air temperature, } \\
\text { unsatisfied occupants increased energy } \\
\text { use because of increased ventilation } \\
\text { cooling or heating, deviating supply- } \\
\text { and exhaust airflow from the designed } \\
\text { value }\end{array}$ \\
\hline 7 & $\begin{array}{l}\text { Higher energy } \\
\text { consumption than } \\
\text { designed }\end{array}$ & $\begin{array}{l}\text { - Not designed } \mathrm{V}_{\min } \text { and } \mathrm{V}_{\max } \text { (AHU operates as a constant } \\
\text { volume ventilation strategy) } \\
\text { - Lights are left on } 24 / 7 \text { (light sensor or schedule might not be } \\
\text { working) } \\
\text { - Cooling and heating coils operate on/off from wrong } \\
\text { installation or wear and tear } \\
\text { - Abnormal user-behavior } \\
\text { - The heating system in the room is set to max (heating 24/7) } \\
\text { - Windows are frequently opened }\end{array}$ & $\begin{array}{l}\text { Additional energy cost may increase, the } \\
\text { building may not reach energy goal if } \\
\text { part of an energy/sustainability scheme }\end{array}$ \\
\hline 8 & Blocked filters & $\begin{array}{l}\text { - No cleaning or change of filters } \\
\text { - No access to the DCV-damper }\end{array}$ & $\begin{array}{l}\text { Deviating supply- and exhaust airflow, } \\
\text { air feels heavy due to lower supply of } \\
\text { air }\end{array}$ \\
\hline 9 & $\begin{array}{l}\text { Improper commissioning } \\
\text { (faults found due to } \\
\text { unsatisfactory / not } \\
\text { finished commissioning) }\end{array}$ & $\begin{array}{l}\text { - No ventilation documentation provided or missing/non- } \\
\text { existing FDV-documentation } \\
\text { - Improper installation } \\
\text { - PID coefficients in DCV-damper not calibrated } \\
\text { - DCV-damper pressure control frozen, or poor/wrong system } \\
\text { operating setpoints }\end{array}$ & $\begin{array}{l}\text { Deviating supply air temperature and } \\
\text { supply airflow, unbalance, fouling } \\
\text { components in the HVAC system, } \\
\text { increased energy use }\end{array}$ \\
\hline 10 & $\begin{array}{l}\text { Building Management } \\
\text { System (BMS) does not } \\
\text { show necessary } \\
\text { parameters for efficient } \\
\text { building operation }\end{array}$ & $\begin{array}{l}\text { - Not optimal BMS } \\
\text { - Wrong choice of BMS for building operation }\end{array}$ & $\begin{array}{l}\text { Deviating supply air temperature and } \\
\text { supply airflow, unbalance, fouling } \\
\text { HVAC system }\end{array}$ \\
\hline
\end{tabular}


Fault 3 low, lower supply air temperature of $17{ }^{\circ} \mathrm{C}$, obviously demonstrates that less energy is needed to heat lower supply airflow, and that the energy demand for supply fan is also smaller at low-temperature airflow. However, it would be expected that space heating increases when supplying with low supply air temperatures. This is due to the electric radiator setpoint, which is set to $19^{\circ} \mathrm{C}$ and is not exceeded even when this fault occurs.

The differences between the reference model and Fault 3 low are low in general. As the supply temperature curve also provides the classroom with $17^{\circ} \mathrm{C}$ when the outdoor temperature exceeds $20^{\circ} \mathrm{C}$, the differences is due to this.

Clearly, Fault 3 high (supply air temperature) will increase ventilation heating since the supply air temperature is $4^{\circ} \mathrm{C}$ higher than the reference.

Although most of the modeled faults increased the annual energy use, two of the faults resulted in decreased energy use. These are Fault 1 low (supply airflow) and Fault 3 low (supply air temperature), which decreased the annual energy use by 2 and $6 \mathrm{kWh} / \mathrm{m} 2$, respectively.

Some investigated faults did not have a significant impact (less than $10 \%$ ) on energy use. These faults were Fault 2 (exhaust airflow) high, and Fault 4 low and high (CO2 concentration setpoint).

\subsection{Thermal comfort}

The results from the fault modeling on thermal comfort measured in operative temperature can be found in Figure 5. The operative temperature was evaluated after the Norwegian building regulations recommendations [22]. The threshold values are hours $<19{ }^{\circ} \mathrm{C}$ and $>26^{\circ} \mathrm{C}$. In addition, the range between 19 and $26{ }^{\circ} \mathrm{C}$ were divided into categories ranging from $\mathrm{IV}+$ and IV- and are described in the legend in Figure 5. The impact of the offset values on the operative temperature is not of especially important since the operative temperature intervals are always above $19{ }^{\circ} \mathrm{C}$ and below $26{ }^{\circ} \mathrm{C}$. Clearly, Fault 3 high increased the time above 24.5 and 26 ${ }^{\circ} \mathrm{C}$ with $10 \%$ due to the higher constant supply air temperature of $25^{\circ} \mathrm{C}$.

\subsection{Indoor air quality}

The indoor air quality, measured as $\mathrm{CO}_{2}$ concentration, is evaluated after the Norwegian labor inspection, report 444 , which recommends keeping the $\mathrm{CO}_{2}$ concentration level below $1000 \mathrm{ppm}$ [23]. The threshold category values are described in the legend in Figure 6.

As seen in Figure 6, 60\% of the occupied hours in the classroom were below the threshold value of Category I, and $40 \%$ of the occupied hours were below the threshold value in Category II. Nevertheless, Fault 4 high achieved $40 \%$ above Category III, which is far above the Norwegian Labor Inspection recommendations. Obviously, increasing the $\mathrm{CO}_{2}$ concentration setpoint will result in a lower airflow supplied to the classroom.

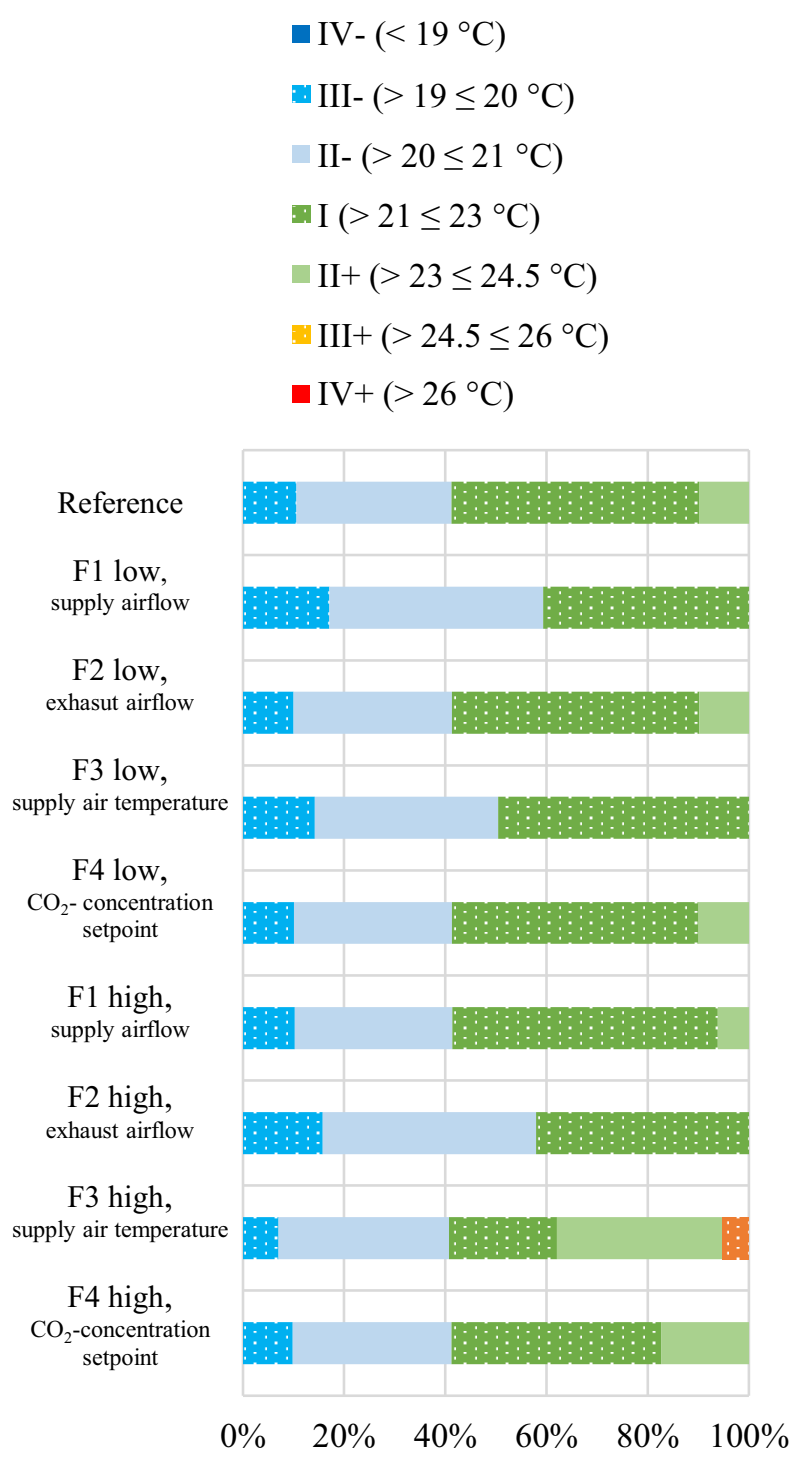

Fig. 5. Distribution of the percentage of occupied hours within each thermal comfort (operative temperature) category for reference and the eight faulty models.

\subsection{Strengths and limitations}

To the best of our knowledge, this study is one of the few studies which has assessed fault modeling in a DCVsystem in a Nordic climate. Our fault modeling approach is well suited, as shown by the evaluated literature. We chose to select faults based on the interview objects, as they possess expert and hands-on knowledge about HVAC systems and can associate typical faults for various ventilation systems in Norway. Thus, the selected faults can be considered more relevant than from a literature review. A wider span of interview objects could provide a broader understanding of the causes of faults and symptoms. However, measures were taken to achieve quality results, such as the interview criteria. A single classroom with one surface towards the outside and the remaining surfaces were treated with no heat exchange were simulated. In a real building, some rooms have larger external surfaces than others, adjoining rooms may 


$$
\begin{aligned}
& \text { III }(>1000 \mathrm{ppm}) \\
& \text { II }(>800 \leq 1000 \mathrm{ppm}) \\
& \text { I }(<800 \mathrm{ppm})
\end{aligned}
$$

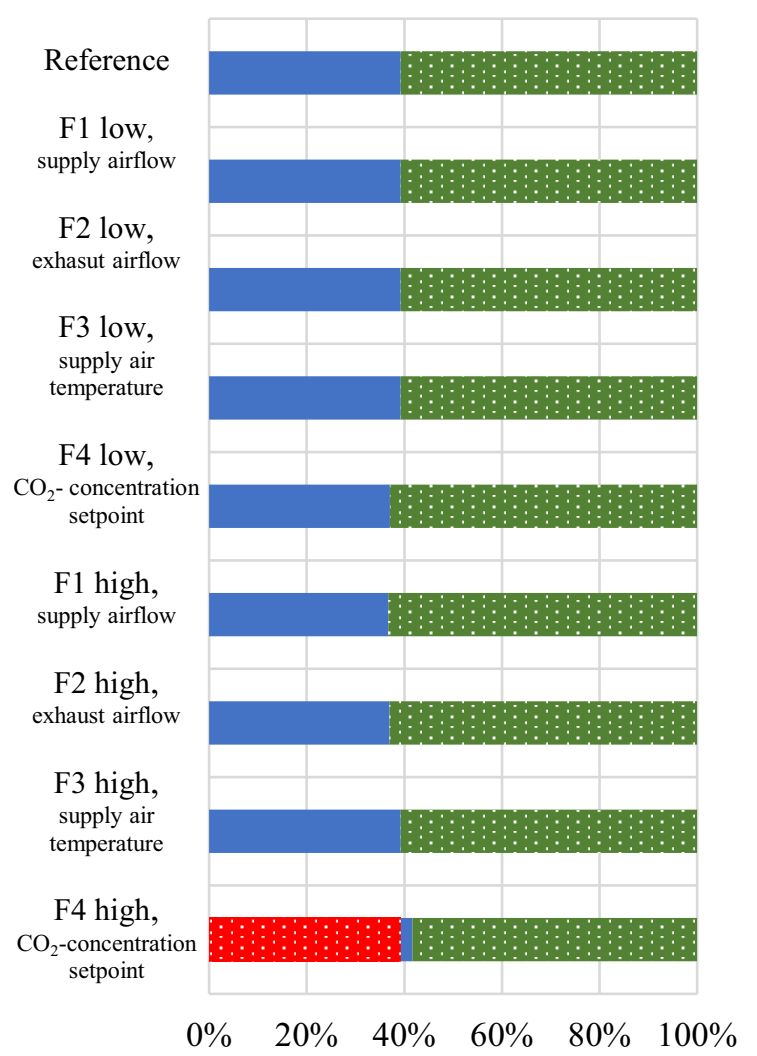

Fig. 6 Distribution of the percentage of occupied hours within each indoor air quality $\left(\mathrm{CO}_{2}\right.$ concentration) category for reference and the eight faulty models.

have different usage and temperatures, and the specific fan power will depend on the total ventilation rates in the AHU. Also, internal walls in a building have leak areas, such as cracks under doors, through internal wall constructions and openings. Only one surface and a door were designed with a leak area in IDA ICE, except the external wall. In addition, since the local fault modeling approach is based on a numerical approach, some deviation from real life may occur.

The chosen extreme values in the local OAT approach are an uncertain factor and are based on information received from the interview objects.

The presented causes of faults and symptoms may represent a large number of other faults not investigated or stated in this study and thus affect that installation faults are the majority of fault occurrence.

Furthermore, this study only investigates the impact of the fault with the same occupancy load, lights, equipment, and schedule every day (deterministic). In reality, the actual occupancy load and schedule may frequently vary both during the day and during the week, as classrooms are used differently. For example, the lower grades rarely have a fixed time schedule. Thus, the consequences in a real situation will deviate from those simulated with these simplifications.

\section{Conclusion}

This study aimed to investigate how typical faults in a DCV-system could influence energy use, thermal comfort, and indoor air quality in a classroom located in a Nordic country. The faults with the highest impact increased energy use by $77 \%$ and $60 \%$, respectively. Furthermore, the faults also influenced both thermal comfort and indoor air quality.

Our findings demonstrate that faults in DCV-systems can have considerable consequences for energy use and indoor environment. To design, build, and operate healthy and energy-efficient buildings using DCV-system, further efforts are recommended to identify where, when, why, and how often such faults occur.

As a continuation of this study, statistical analyses on fault probability and occurrence would allow for more investigations regarding fault impact on various output parameters. In addition, Monte Carlo simulations may be performed to analyze how higher-order faults interact with each other.

This paper is based on the master thesis by Kamilla Heimar Andersen and was a part of the BEST VENT project. BEST VENT is funded by the Research Council of Norway EnergiX program under Grant 255375/E20 together with the industry partners: Undervisningsbygg Oslo KF, GK Inneklima AS, DNB Næringseiendom AS, Erichsen \& Horgen AS, Hjellnes Consult AS, Multiconsult AS, Interfil AS, Camfil Norge AS, Swegon AS, Belimo Automasjon Norge AS, NEAS AS, and Norsk VVS Energi- og Miljøteknisk Forenings Stiftelse for forskning.

We would like to thank the 12 interview participants who contributed with the content of this study, hence the faults and symptoms, causes, and consequences of faults occurrence in DCV-dampers.

\section{References}

[1] European Commission, Official Journal, 13-35 (2010)

[2] Core Writing Team, R.K. Pachauri and L.A. Meyer, IPCC, (2014)

[3] ECTP Innovative Built Environment, Strategic Research \& Innovation Agenda, 79-100, (2019)

[4] J. Andersson, A. Boerstra, D. Clements-Croome, K. Fitzner, and S. O. Hanssen, REHVA guidebook No. 6, (2007)

[5] J. Hyvarinen and S. Karki, IEA Annex 25: Building Optimization and Fault Diagnosis Source Book, (1996)

[6] P. Taylor, S. Katipamula, and M. R. Brambley, HVAC\&R, 11, 169-187, (2014)

[7] R. Sterling, G. Provan, J. Febres, D. O’Sullivan, P. Struss, and M. M. Keane, Energy Procedia, 62, 686-693, (2014)

[8] M. Najafi, D. M. Auslander, P. L. Bartlett, P. Haves, and M. D. Sohn, Applied Energy, 96, 347-358, (2012)

[9] K. W. Roth, P. Llana, and M. Feng, International $R \& A C$ Conference, (2004) 
[10] M. Basarkar, Pang, X. Pang, L. Wang, P. Haves, and H. Tianzhen, Building Simulation, 28972903, (2011)

[11] A. Tallet, K. M. M. Merghani, and C. Inard, 12th REHVA World Congress, 8, (2016)

[12] M. Mysen, S. Berntsen, P. Nafstad, and P. G. Schild, Energy and Buildings, 37, 1234-1240, (2005)

[13] M. J. Brandemuehl and J. E. Braun, ASHRAE Transactions, 105, (1999)

[14] B. J. Wachenfeldt, M. Mysen, and P. G. Schild, Energy and Buildings, 39, 1073-1079, (2007)

[15] M. Mysen, P. Schild, A. Cablé, SINTEF Research, Demand-controlled ventilation requirements and commissioning, (2014)

[16] M. Mysen and P. G. Schild, SINTEF Research, Behovsstyrt ventilasjon, DCV - forutsetninger og utforming, (2016)

[17] Y. Li and Z. O’Neill, Building Simulation, 11, 953-975, (2018)

[18] P. Haves, Proceedings of Building Simulation'97, (1997)

[19] J. Qin and S. Wang, Energy and Buildings, 37, 1035-1048, (2005)

[20] S. Ginestet, D. Marchio, and O. Morisot, Energy and Buildings, 40, 51-57, (2008)

[21] R. Zhang and T. Hong, Applied Energy, 202, 178-188, (2017)

[22] Direktoratet for byggkvalitet (DiBK), Norwegian Building Regulation Byggteknisk forskrift (TEK17), (2017)

[23] Norwegian Labour Inspection, Klima og luftkvalitet på arbeidsplassen no. 444, (2012) 